\title{
Efficacy of Endodontic Treatment on the Persistence of Selected Endodontic Pathogens and on Radiographical Periapical Healing
}

\section{Evaluación de la eficacia antimicrobiana y el reparo periapical radiográfico de un protocolo de tratamiento endodóntico}

Jessie Reyes Carmona DDS, MSD, PhD¹; Carolina Ballestero DDS, Esp ${ }^{1}$; Erick Hernández DDS, Esp; Tatiana Ramírez DDS, MSD1; Marianela Benavidez DDS, Esp¹; Pablo Meneses DDS, Esp"; Rodolfo Zeledón DDS, Esp ${ }^{1}$; Sandra Silva de la Fuente MQC, M.Sc²

1. Department of Endodontics, Faculty of Dentistry, University of Costa Rica, Costa Rica.

2. Centro de Investigación en Biología Celular y Molecular, University of Costa Rica, Costa Rica.

Correspondence to: Dra. Jessie Reyes Carmona - jessreyesc@hotmail.com

Received: 17-VIII-2015

Accepted: $30-X-2015$

Published Online First: 9-XI-2015

D0I: http://dx.doi.org/10.15517/ijds.v0i0.22035

\section{ABSTRACT}

The objective of this clinical study was to evaluate by polymerase chain reaction (PCR) the antimicrobial efficacy and the outcome of an endodontic protocol treatment (EPT) performed by undergraduated dental students on infected root canals associated with periapical lesions. Fifty-six patients attending for treatment of pulp necrosis and apical periodontitis were included. A specific EPT approach was performed and DNA extracts were taken at the baseline (S1), after a disinfection-neutralization procedure (S2), post-chemomechanical preparation (S3) and after Intracanal medication (S4) for the presence of specific bacteria. The outcome of the EPT was assessed radiographically using the Periapical Index-system (PAI) after 18-month follow-up. An intergroup evaluation shows that when comparing S1 to $S 3, S 1$ to $S 4, S 2$ to $S 3$, and $S 2$ to $S 4$, the presence of bacteria were significantly reduced $(P<0.05)$. Finally, S4 was not significantly reduced when compared with S3 (P>0.05). The most prevalent species in their respect order were Actinomyces Israelii > Enterococcus Faecalis > Fusobacterium Nucleatum/ Prevotella Nigrescens $>$ Phorphyromonas Endodontalis. After the 18-month follow-up, the overall success rate of root canal - treated teeth was of $88 \%$ (PAl 1 or 2). This In Vivo study demonstrated that EPT significantly reduced the number of cases with positive results for the studied bacteria, showing a profound positive impact in the outcome of endodontic treatment of teeth diagnosed with Pulp Necrosis and Apical Periodontitis.

\section{KEYWORDS}

Apical periodontitis, Endodontic treatment, Polymerase chain reaction, Outcome assessment.

REYES J., BALLESTERO C., HERNÁNDEZ E., RAMÍREZ T., BENAVIDES M., MENESES P., ZELEDÓN M., SILVA S., 2015: Clinical Efficacy of Endodontic Treatment on the Persistence of Selected Endodontic Pathogens and on Radiographical Periapical Healing.-ODOVTOS-Int. J. Dental Sc., 17-2 (MayAugust): $43-52$. 


\section{RESUMEN}

El objetivo de este estudio clínico fue evaluar la eficacia antimicrobiana y el reparo periapical de un protocolo de tratamiento endodóntico (EPT) por medio de la reacción en cadena de polimerasa (PCR), realizado por estudiantes de odontología de pregrado en conductos infectados asociados a lesión periapical. Se incluyeron cincuenta y seis pacientes que requerían tratamiento de una necrosis pulpar y periodontitis apical. Se realizó un EPT específico y se tomaron extractos de ADN al inicio (S1), tras la neutralización inmediata (S2), posterior a la preparación químico mecánica (S3) y posterior a la medicación intraconducto (S4) para identificar la presencia de bacterias específicas. El resultado del EPT se evaluó radiográficamente usando el sistema de índice periapical (PAl) por un período de 18 meses de seguimiento. La comparación entre grupos muestra que cuando se compara S1 con S3, S1 con S4, S2 con S3 y S2 con S4 la presencia de bacterias se redujo significativamente $(P<0.05)$. Finalmente en S4 no hubo un reducción significativa cuando se compara con $S 3$ ( $P>0.05)$. Las especies más prevalentes en su respectivo orden fueron Actinomyces Israelii > Enterococcus Faecalis > Fusobacterium Nucleatum I Prevotella Nigrescens > Phorphyromonas Endodontalis. Posterior a la evaluación de 18 meses, el porcentaje de éxito de los dientes tratados endodónticamente fue de un 88\% (PAl 10 2). Este estudio In Vivo demostró que el EPT redujo significativamente el número de casos positivos para las bacterias estudiadas, demostrando un profundo y positivo impacto en el resultado del tratamiento endodóntico de los dientes diagnosticados con necrosis pulpar y periodontitis apical.

\section{PALABRAS CLAVE}

Periodontitis apical, Tratamiento endodóntico, Reacción en cadena de la polimerasa, Control pos-operatorio.

\section{INTRODUCTION}

Apical periodontitis is a sequel of endodontic infection and establishes as result of the host defense response to microbial challenge proceeding from the root canal system (1). The infected root canal system acts as a reservoir of microbial cells, virulence products, and antigens, which evoke local inflammation, resorption of periapical tissues, and eventual formation of various histopathological categories of apical periodontitis, commonly referred to as periapical lesions (1-4). Because apical periodontitis is recognizably as an infectious disease, optimum treatment outcome can only be achieved when the endodontic infection is properly eradicated or controlled (1-5).

Thus, the prognosis of the endodontic treatment depends, in majority, on successful microbial elimination from the infected root canal system (3). Endodontic infections are treated by chemomechanical preparation, supplemented or not, by an interappointment intracanal medication with calcium hydroxide. These procedures play a critical role in disinfection by causing a considerable reduction in bacterial populations within the main root canal (4). In addition to the mechanical effects of instrumentation and irrigation procedures, the use of an antimicrobial substance, such as sodium hypochlorite for irrigation is indicated because it significantly enhances bacterial elimination (3-5).

Indeed, studies have revealed that the outcome of the endodontic treatment is significantly influenced by bacterial persistence in the root canals at the time of filling (6-10). Thus, research on alternative or in supplementary antimicrobial protocols is of paramount importance in clinical endodontics. 
Even though several in vivo studies have investigated the antibacterial effects of endodontic procedures $(1-4,6-9)$, few have related these findings with radiographic follow-up of periapical healing. Therefore, the aim of this clinical study was to evaluate by polymerase chain reaction (PCR) the antimicrobial efficacy for some specific bacteria and the outcome of an endodontic protocol treatment performed by under-graduated dental students on infected root canals associated with periapical lesions.

\section{MATERIALS AND METHODS}

\section{CASE SELECTION}

Fifty-six patients attending in 2011 for evaluation and treatment of apical periodontitis to the clinic of endodontic were included in this examination. The informed written consent was obtained from all participants, which guarantees that the EPT was the same independent if allow participation or not in this quality control outcome assessment.

Each patient contributed one tooth, and selection included the following inclusion/ exclusion criteria $(3,4)$. For inclusion, teeth had to be single-rooted and single-canalled with intact pulp chamber walls, necrotic pulps confirmed by sensitivity pulp tests, and clinical and radiographic evidence of asymptomatic apical periodontitis. All teeth had apical bone radiolucencies ranging in size from $2 \times 3 \mathrm{~mm}$ to $8 \times 10 \mathrm{~mm}$ (4). Exclusion criteria involved teeth from patients who received antibiotic therapy within the previous three months, teeth with extense carious lesions, teeth with root or crown fracture, teeth subjected to previous endodontic treatment, symptomatic teeth, and patients with periodontal disease.

\section{TREATMENT AND SAMPLING PROCEDURES}

Supragingival biofilms were removed from each tooth by scaling and cleansing with pumice. Caries and/or defective coronal restorations were then removed by using sterile high-speed and low-speed burs. After rubber dam application, the operative field was cleaned and disinfected with $0.12 \%$ chlorhexidine gluconate. After completing the access preparation with another sterile bur under saline irrigation, the operative field, now including the pulp chamber, was once again cleaned and disinfected as above. NaOCL was neutralized with $5 \%$ sodium thiosulfate, and sterility control samples were taken from the tooth surface with sterile paper points. For inclusion of the tooth in the study, these control samples had to be uniformly negative after PCR with universal bacterial primers $(3,4)$. Six teeth were excluded because of the positive results during the sterility controls.

Afterwards, a microbiologic sample was taken from the root canal immediately before any chemomechanical procedure (S1 sample). For sample taking, sterile saline solution was placed in the pulp chamber without overflowing, and a small instrument was used to carry the solution into the canal $(3,4)$. The root canal walls were gently filed with the small instrument in order to suspend the canal contents in saline. Three sterile paper points were consecutively placed in the canal to a level approximately $1 \mathrm{~mm}$ short of the root apex and used to soak up the fluid in the canal. Each paper point was left in the canal for 1 minute and then transferred to cryotubes containing Trisethylenediaminetetraacetic acid (EDTA) buffer ( $\mathrm{pH}$ 7.6) and immediately frozen at -20 Co.

Furthermore, an initial disinfectationneutralization procedure of the septic-toxic- 
necrotic residues on the main root canal was performed. Each third of the root in a crown down manner were irrigated with $1 \mathrm{ml}$ of $5 \%$ NAOCL and agitated for 1 minute. Each canal was dried by using sterile paper points and then flushed with $5 \mathrm{~mL}$ of $5 \%$ sodium thiosulfate to inactivate any $\mathrm{NaOCl}$ residual. Then, a second microbiological sample was taken in order to evaluate the clinical efficacy of this supplementary approach (S2). Immediately, chemomechanical preparation was completed at the same appointment in all cases. A manual preparation with the Hybrid technique was used to prepare all canals. Briefly, the coronal two thirds of the root canals were enlarged with GatesGlidden burs. The working length was established $1 \mathrm{~mm}$ short of the apical foramen with an apex locator (Root ZX II, J Morita, U.S.A) and confirmed by radiographs. Apical preparation was completed to the working length with Flexo-file (DentsplyMaillefer, Switzerland). Master apical files ranged from \#35-\#60, depending on both root anatomy and initial diameter of the root canal. Patency of the apical foramen was confirmed with a small file (\#15 or \#20 Flexofile) throughout the procedures and after each file size. Preparation was completed by using step-back of 1-mm increments. A 27-gauge needle was used to deliver $2 \mathrm{~mL}$ of $2.5 \% \mathrm{NaOCl}$ after each instrument size. Smear layer was removed by rinsing the canal with $3 \mathrm{~mL}$ of $17 \%$ EDTA and then leaving the canal filled with this solution for 3 minutes. After a final irrigation with $3 \mathrm{~mL}$ of $2.5 \% \mathrm{NaOCl}$, the canal was prepared for a post-instrumentation sample (S3) as outlined above.

Then, the canal was dried with sterile paper points and medicated with calcium hydroxide paste (Ultradent, USA) and packed with a cotton pellet at the level of canal entrance. A radiograph was taken to ensure proper placement of the calcium hydroxide paste in the canal. Access cavities were filled with at least 4-mm thickness of temporary cement (Coltosol; Coltene/Whaledent Inc, USA).
Eight days later, the tooth was isolated with a rubber dam, the operative field was cleaned and disinfected, and the $\mathrm{NaOCl}$ neutralized, as previously described. A sterility control sample of the operative field was obtained. The temporary filling was removed, and the calcium hydroxide paste was rinsed out of the canal by using sterile saline solution and the master apical file. The root canal walls were gently filed, and a post medication sample (S4) was taken. Subsequently, the canals were filled with gutta-percha and sealer by the lateral condensation technique, and the tooth was restored with glass ionomer cement or composite resin (3M Espe, USA).

\section{DNA EXTRACTION}

Clinical samples were brought to room temperature, and DNA was extracted using the Maxwell@ 16 Viral Total Nucleic Acid Purification Kit $\circledast$ (AS1150) (Promega, USA), following the protocol recommended by the manufacturer.

\section{PCR ASSAY}

Aliquots of extracted DNA were used in 16S rRNA gene-based PCR protocols using universal primers for Actinomyces israelii, Enterococcus faecalis, Fusobacterium nucleatum, Phorphyromonas endodontalis and Prevotella Nigrescens (Table 1). PCR reactions were performed in $50 \mathrm{uL}$ of reaction mixture containing $1 \mathrm{mmol} / \mathrm{L}$ concentrations of each primer, $5 \mathrm{uL}$ of $10 \mathrm{PCR}$ buffer (Sigma, Aldrich, USA), 3 mmol/L MgCl2, 1.25 U of Taq DNA polymerase (Sigma), and $0.2 \mathrm{mmol} / \mathrm{L}$ of each desoxyribonucleoside triphosphate (Sigma). Positive and negative controls were included in each batch of samples analyzed. Positive controls consisted of DNA extracted from Porphyromonas gingivalis (ATCC 33277). Negative controls consisted of sterile ultrapure water instead of sample. All reactions were run in triplicate. 
Table 1. Primers used in the present study

\begin{tabular}{lll}
\hline \multicolumn{1}{c}{ GEN } & \multicolumn{1}{c}{ SENSE } & \multicolumn{1}{c}{ ANTISENSE } \\
\hline Actinomycesisraelii & TAACCTGCCCCTCACTTCTG & GAGTCTGGGCCGTATCTCAG \\
Enterococcus faecalis & TCTGGCTGTGCCGCATGGTG & GGGCTTCCGTTCAGCCCCAC \\
Fusobacterium nucleatum & ACGCTGGGCTACACACGTGC & TTGTGGTGTGACGGGCGGTG \\
Phorphyromonasendodontalis & CCGAAGAGATTCCTCTCACG & GGACTGGCTAATGTCGTCGT \\
Prevotellanigrescens & GGTGCGACGATAACAACCT & TAGGCATCAGCACGAAAGTG \\
\hline
\end{tabular}

PCR amplifications were performed in a DNA thermocycler (Applied Biosystems, Thermo Fisher Scientific Inc., USA). Cycling conditions were as follows: initial denaturation at $95^{\circ} \mathrm{C} / 4 \mathrm{~min}, 32$ cycles at $95^{\circ} \mathrm{C} / 60 \mathrm{~s}, 55^{\circ} \mathrm{C} / 60 \mathrm{~s}$, and $72^{\circ} \mathrm{C} / 1 \mathrm{~min}$, and final extension at $72^{\circ} \mathrm{C} / 5 \mathrm{~min}$.

PCR products were subjected to electrophoresis in a $2 \%$ agarose gel-Tris-borateEDTA buffer. The gel was stained (Biotium, USA), visualized and digitalized in Image $J ®(\mathrm{NIH}, \mathrm{USA})$. The presence of amplicons of the expected size for each primer pair was considered a positive result and analyzed in a descriptive manner. The Mann-Whitney test was used to evaluate the reduction in the number of each target bacteria from S1 to S2, S1 to S3, S1 to S4, S2 to S3, S2 to S4, and S3 to S4 (intergroup analysis). Moreover, the number of taxa persisting at S4 after medication with each bacteria was analyzed in a descriptive manner. The significance level was set at $5 \%(P<0.05)$.

\section{RADIOLOGICAL FOLLOW-UP}

The outcome of the endodontic treatment was assessed radiographically using the PAI-system (Table 2)(10-11). The radiological examination was done with individually bite-mounted radiograph holders throughout the follow-up period. Control radiographs were taken at 6,12 , and 18 months after the therapy and the PAI scores were recorded. Two observers were previously calibrated (and examined the radiographs individually reaching a 90\% agreement (Kappa: 0.60-0.81). Thus, a third experiment endodontist was consulted in the cases for which disagreement occurred. All results were tabulated and evaluated for descriptive considerations.

Table 2. Periapical Index

\begin{tabular}{ll}
\hline $\begin{array}{c}\text { PAI } \\
\text { Score }\end{array}$ & \multicolumn{1}{c}{ Description } \\
\hline 1 & Normal periapical structure \\
2 & Small changes in bone structure \\
3 & Changes in bone structure with some mineral loss \\
4 & Periodontitis with well-defined radiolucent area \\
5 & Severe periodontitis with elements indicating \\
& expansion of the lesion \\
\hline
\end{tabular}

\section{RESULTS}

\section{PCR ASSAY}

All S1 samples yielded positive for each bacteria. Overall, The Initial Neutralizationdisinfection procedure significantly reduced the number of positive PCR results for all species ( $P$ $<0.05)$. An intergroup evaluation shows that when comparing S1 to S3, S1 to S4, S2 to S3, and S2 to S4 the presence of bacteria were significantly reduced $(P<0.05)$. Otherwise, S4 was not significantly reduced when compared with $S 3(P>0.05)$.

The most prevalent taxa in S2 were Actinomyces Israelii (88\%) and Enterococcus Faecalis (84\%). However, all species were reduced after this supplementary approach. 
After chemomechanical preparation (S3 samples) the most prevalent species in their respect order were Actinomyces Israelii > Enterococcus Faecalis > Fusobacterium Nucleatum/Prevotella Nigrescens > Phorphyromonas Endodontalis. Moreover, S4 samples reveals the prevalence of Actinomyces Israelii (16\%), Enterococcus Faecalis (14\%) and Phorphyromonas Endodontalis (2\%), the results are depicted in table 3 and figure 1.

\section{RADIOLOGICAL FOLLOW-UP}

After the 18-month follow-up of the 50 root canal treatment performed in this study, 32
(64\%) were from women and 18 (36\%) from men. Superior incisors were the most frequently treated teeth, followed by mandibular premolars.

The overall success rate of root canal treated teeth was of $88 \%$ (PAl 1 or 2) (Figure 2). Furthermore, 4 cases were considered PAI 3, 1 case PAI 4 and 1 case PAI 5 (Table 4).

It is important to highlight that the 6 cases related to unsuccessful treatment showed the persistence of bacteria in S4 samples, proving the influence of residual bacteria on the outcome of endodontic treatment.

Table 3. Incidence of positive results in samples taken before treatment (S1), Post-Initial Disinfection (S2), Post-instrumentation (S3), and, Post-medication (S4).

Number of Cases $=50(100 \%)$

\begin{tabular}{lllll}
\hline \multicolumn{1}{c}{ Species } & \multicolumn{1}{c}{$\begin{array}{c}\text { S1 } \\
\text { (Initial) }\end{array}$} & $\begin{array}{c}\text { S2 } \\
\text { (Post-Initial } \\
\text { Disinfection) }\end{array}$ & $\begin{array}{c}\text { S3 } \\
\text { (Post- } \\
\text { Instrumentation) }\end{array}$ & $\begin{array}{c}\text { S4 } \\
\text { (Post-medication) }\end{array}$ \\
\hline ActinomycesIsraelii & $50 / 50(100 \%)$ & $44 / 50(88 \%)$ & $15 / 50(30 \%)$ & $8 / 50(16 \%)$ \\
Enterococcus Faecalis & $50 / 50(100 \%)$ & $42 / 50(84 \%)$ & $14 / 50(28 \%)$ & $7 / 50(14 \%)$ \\
Fusobacterium Nucleatum & $50 / 50(100 \%)$ & $25 / 50(50 \%)$ & $4 / 50(8 \%)$ & $0 / 50(0 \%)$ \\
PhorphyromonasEndodontalis & $50 / 50(100 \%)$ & $30 / 50(60 \%)$ & $6 / 50(12 \%)$ & $1 / 50(2 \%)$ \\
PrevotellaNigrescens & $50 / 50(100 \%)$ & $26 / 50(52 \%)$ & $4 / 50(8 \%)$ & $0 / 50(0 \%)$ \\
\hline
\end{tabular}

Number of cases with positive result/number of cases examined (\%).

Table 4. Periradicular status of root canal-treated teeth after 18-month radiological Follow-up.

\begin{tabular}{cc}
\hline PAI & Number of Cases (\%) \\
\hline 1 & $32(64 \%)$ \\
2 & $12(24 \%)$ \\
3 & $4(8 \%)$ \\
4 & $1(2 \%)$ \\
5 & $1(2 \%)$ \\
\hline
\end{tabular}

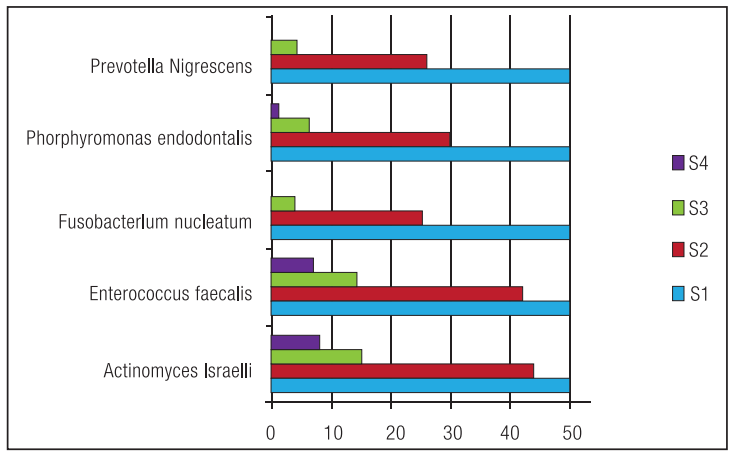

Figure 1. Number of cases with positive result examined before treatment (S1), Post-Initial Disinfection (S2), Post-instrumentation (S3), and, Post-medication (S4). 


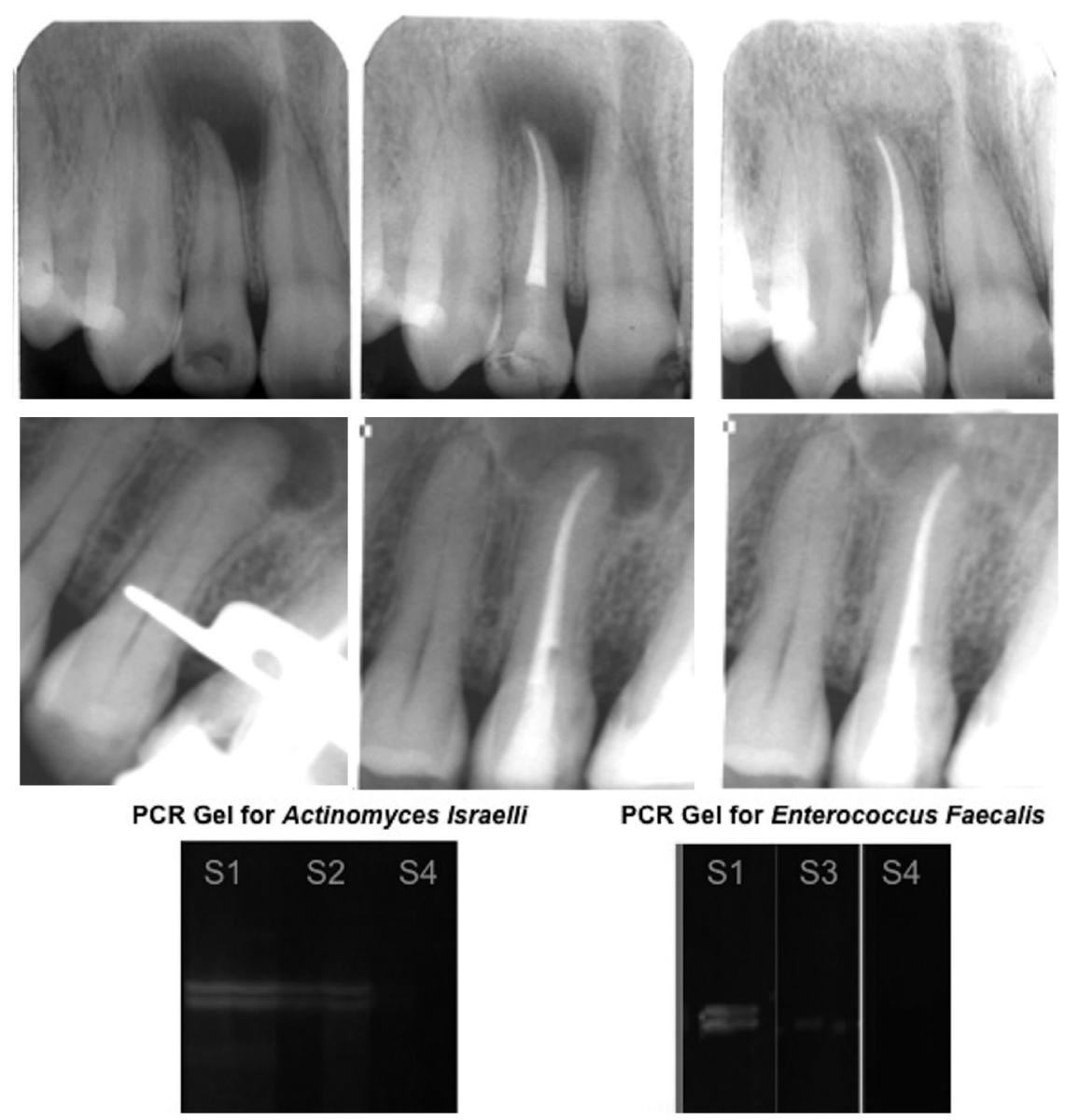

Figure 2. Illustration of a Root Canal treated tooth tabulated as PAI 2 after 18-month radiological Follow-up. Demonstrative PCR Gel showing positive and negative results for bacteria identification (before treatment - S1, Post-Initial Disinfection - S2, Post-instrumentation - S3, and, Postmedication - S4).

\section{DISCUSSION}

The effect of different treatment procedures on microbial elimination of infected root canal and its impact on the radiological observed healing of the periapical lesion was studied. This, in vivo research, evaluated the persistence of specific bacteria through endodontic procedures. The anaerobic species of Fusobacterium nucleatum, Phorphyromonas endodontalis and Prevotella Nigrescens were previously associated with Primary Endodontic Infection, suggesting their involvement in the pathogenesis of perirradicular diseases (3-4, 6, 10, 12). Moreover, Actinomyces israelii and Enterococcus faecalis are associated with unsuccessful endodontic outcome treatment or persistent perirradicular disease $(5,10,12-17)$.

The incidence of molecular positive results decreased after all treatment procedures. At the Initial samples (S1), all 50 cases showed the presence of the studied bacteria. It is important to highlight, that this study tested the Initial disinfection procedure (S2), by irrigating with NaOCL $5 \%$ in a crown down manner, in order to diminish and neutralize the toxic-septic-necrotic residues of the root canal in teeth with pulp necrosis and periapical lesions. This supplementary approach promotes a reduction of all the studied bacteria, reaching statistical significance with the initial sample size analyzed. 
Therefore, our results confirm that the chemomechanical preparation plays a crucial role in reducing infection in the main root canal. Although these parameters were still reduced after Intracanal medication with calcium hydroxide, the results failed to reach statistical significance when compared with chemomechanical procedures. However, its well known that the sterilization of the root canal system is virtually an unattainable goal with the available techniques and substances (1720), an optimal outcome of endodontic treatment will depend on maximal reduction of the bacterial load to levels that are compatible with periradicular tissue healing $(6,21-22)$. Thus, despite there were no statistical difference after the use of Intracanal medication, it was possible to obtain a considerable decreased in the number of positive DNA bacteria detection. Paiva et al. (21) suggested that there is a threshold of bacterial infection level below which tissue healing can occur. Because this threshold is unknown, treatment should promote as maximal reduction as possible in the bacterial load (21, 22). For this reason, the use of calcium hydroxide as an Intracanal medication is highly encouraged, specially in teeth with endodontic infection and perirradicular disease.

Accurate analysis of antimicrobial effects on treatment by means of DNA-based molecular microbiologic could be hampered (4). The higher incidence of positive results after molecular methods is expected and is highly likely to be related to the higher sensitivity of the method or the ability to detect as-yet-uncultivated bacteria (4). However, the possibility of detecting DNA from cells that were recently killed cannot be discarded, although previous studies have suggested that this may not be such a highly significant problem as previously thought $(3,4,23,24)$.

Previous studies emphasize that a worldwide improvement in the quality of root canal treatment in general dental practice is required in order to promote perirradicular health $(11,25,26)$. Our results showed that this endodontic protocol treatment performed by under-graduated dental students on infected root canals associated with perirradicular lesions have an $88 \%$ of radiographical success.

The evaluation of periapical healing with just periapical radiographs is allegedly of incomplete diagnostic value (11), because cracks and marginal infiltration in restorations might not be well identified. Moreover, apical periodontitis lesions limited to the cancellous bone might pass unnoticed $(4,11,27$, 28). Thus, further studies evaluating the impact of a disinfection approach on the outcome of endodontic treatment may include more sensitive techniques, such as cone beam computed tomography.

However, the correlation of PCR results with the radiological follow-up demonstrates that in the six cases tabulated as unsuccessful (PAI 3, 4 and 5) were detectable the persistence of Actinomyces israelii and Enterococcus faecalis after Intracanal medication or before obturation. Our present findings are in agreement with previous reports that demonstrate that the presence of these bacteria per se was associated with endodontic treatment failures (10,14-16). Bacteria can endure the effects of antimicrobial procedures usually because they are located in areas not reached by instruments and irrigants (1). However, our finding that several other species were found in S3 and S4 samples might also indicate that bacterial persistence can be related to factors other than the intrinsic resistance to treatment procedures and substances $(4,6)$. For instance, bacteria organized in intrarradicular biofilm communities can be collectively more resistant to antimicrobial agents, and those present in anatomical irregularities can evade the effects of instruments, irrigants, and even medications. Moreover, the persistence of bacteria must sustain perirradicular disease. This may help explain the present results. 
In conclusion, this study demonstrated that the endodontic protocol treatment significantly reduced the number of cases with positive results for the studied bacteria, showing a profound positive impact in the outcome of endodontic treatment of teeth diagnosed with pulp necrosis and apical periodontitis. However, bacteria remained detectable in some cases. Because of this, it should be emphasized the need of future studies in order to develop alternative methods or substances to improve disinfection of the root canal before filling.

\section{ACKNOWLEDGMENTS}

The authors deny any conflicts of interest related to this study. A special acknowledgment to PhD Jacques Nör, University of Michigan for the obtainment of bacterial primers and for the establishment of the protocol in the Lab. Angiogenesis used in this study.

\section{REFERENCES}

1. Nair, P. N. R. Pathogenesis of apical periodontitis and the causes of Endodontic failures. CROBM. November 2004; 15: 348-381.

2. SiqueiraJF Jr. Treatmentofendodontic infections. London: Quintessence Publishing; 2011.

3. Rocas I. N \&Siqueira JF Jr. Comparison of the In Vivo Antimicrobial Effectiveness of Sodium Hypochlorite and Chlorhexidine Used as Root Canal Irrigants: A Molecular Microbiology Study. J Endod 2011; 37: 143-150.

4. Rocas I. N. \& Siqueira JF Jr. In Vivo Antimicrobial Effects of Endodontic Treatment Procedures as Assessed by Molecular Microbiologic Techniques.

5. Ricucci D., Siqueira JF Jr. Biofilms and apical periodontitis: study of prevalence and association with clinical and histopathologic findings. J Endod 2010; 36: 1277-88. 3.

6. Siqueira JF Jr, Rocas IN. Clinical implications and microbiology of bacterial persistence after treatment procedures. J Endod 2008; 34:1291-301. e3. 4.

7. Trope M, Debelian G. Endodontic treatment of apical periodontitis. In: Ørstavik D, Pitt Ford T, eds. Essential endodontology. 2nd ed. Oxford, UK: Blackwell Munksgaard Ltd; 2008:347-80.

8. Ricucci D, Siqueira JF Jr. Biofilms and apical periodontitis: study of prevalence and association with clinical and histopathologic findings. J Endod 2010; 36: 1277-88.

9. Rôças IN, Siqueira JF Jr, Aboim MC, Rosado AS. Denaturing gradient gel electro- phoresis analysis of bacterial communities associated with failed endodontic treatment. Oral Surg Oral Med Oral Pathol Oral RadiolEndod 2004;98:741-9.

10. Sundqvist G, Figdor D, Persson S, Sjogren U. Microbiologic analysis of teeth with failed endodontic treatment and the outcome of conservative re-treatment. Oral Surg Oral Med Oral Pathol Oral RadiolEndod 1998;85:86-93.

11. Tavares P. et al. Prevalence of Apical Periodontitis in Root Canal-Treated Teeth From an Urban French Population: Influence of the Quality of Root Canal Fillings and Coronal Restorations. J Endod 2009; 35: 810-813.

12. Siqueira JF Jr, Rôças IN. Polymerase chain reaction-based analysis of microorganisms associated with failed endodontic treatment. Oral Surg Oral Med Oral Pathol Oral RadiolEndod 2004; 97 :85-94.

13. Pinheiro ET, Gomes BP, Ferraz CC, Sousa EL, Teixeira FB, Souza-Filho FJ. Microorganisms from canals of root-filled teeth with periapical lesions. IntEndod J 2003;36:1-11.

14. Molander A, Reit C, Dahlen G ,Kvist T. Microbiological status of root-filled teeth with apical periodontitis. IntEndod J 1998;31:1-7.

15. Gomes BP, Pinheiro ET, Jacinto RC, Zaia AA, Ferraz CC, Souza-Filho FJ. Microbial analysis of canals of root-filled teeth with 
periapical lesions using polymerase chain reaction. J Endod 2008;34:537- 40.

16. Lin LM, Pascon EA, Skribner J, Gangler $\mathrm{P}$, Langeland $\mathrm{K}$. Clinical, radiographic, and histologic study of endodontic treatment failures. Oral Surg Oral Med Oral Pathol 1991;71:603-11.

17. Rôças IN, Jung IY, Lee CY, Siqueira JF Jr. Polymerase chain reaction identification of microorganisms in previously root-filled teeth in a South Korean population. J Endod 2004;30:504-8.

18. Fabricius L, Dahlén G, Sundqvist G, Happonen RP, Möller AJR. Influence of residual bacteria on periapical tissue healing after chemomechanical treatment and root filling of experimentally infected monkey teeth. Eur J Oral Sci 2006; 114:278 - 85.

19. Nair PN, Henry S, Cano V, Vera J. Microbial status of apical root canal system of human mandibular first molars with primary apical periodontitis after "one-visit" endodontic treatment. Oral Surg Oral Med Oral Pathol Oral RadiolEndod 2005; 99:231-52.

20. Vera J, Siqueira JF Jr, Ricucci D, et al. Oneversus two-visit endodontic treatment of teeth with apical periodontitis: a histobacteriologic study. J Endod 2012;38: 1040-52.

21. Paiva S, et al. Molecular Microbiological Evaluation of Passive Ultrasonic Activation as a Supplementary Disinfecting Step: A Clinical Study. J Endod 2013; 39: 190-194.

22. Sjögren U, Figdor D, Persson S, Sundqvist $\mathrm{G}$. Influence of infection at the time of root filling on the outcome of endodontic treatment of teeth with apical periodontitis. IntEndod J 1997;30:297-306.

23. Sakamoto M, Siqueira JF Jr, Rocas IN, Benno Y. Bacterial reduction and persistence after endodontic treatment procedures. Oral MicrobiolImmunol 2007;22:19-23.

24. Alves FR, Rocas IN, Almeida BM, Neves MA, Zoffoli J, Siqueira JF Jr. Quantitative molecular and culture analyses of bacterial elimination in oval-shaped root canals by a single-file instrumentation technique. IntEndod J 2012 Mar 8. doi: 10.1111/j.

25. Waltimo T, Trope M, Haapasalo M, Orstavik D. Clinical efficacy of treatment pro- cedures in endodontic infection control and one year follow-up of periapical heal- ing. J Endod 2005;31:863- 6 .

26. Torabinejad M, Ung B, Kettering JD. In vitro bacterial penetration of coronally un- sealed endodontically treated teeth. $\mathrm{J}$ Endod 1990;16:566-9.

27. Siqueira JF Jr, Guimarães Pinto T, Rôças IN. Effects of chemomechanical preparation with $2.5 \%$ sodium hypochlorite and intracanal medication with calcium hydroxide on cultivable bacteria in infected root canals. $\mathrm{J}$ Endod 2007;33:800 -5. 47.

28. Siqueira JF Jr, Magalhães KM, Rôças IN. Bacterial reduction in infected root canals treated with $2.5 \% \mathrm{NaOCl}$ as an irrigant and calcium hydroxide/camphorated paramonochlorophenol paste as an intracanal dressing. J Endod 2007;33:667-72. 